INSTITUTE OF FORESTRY • BELGRADE

INSTITUT ZA ŠUMARSTVO • BEOGRAD

SUSTAINABLE FORESTRY

COLLECTION 65-66, 2012
ODRŽIVO ŠUMARSTVO

ZBORNIK RADOVA 65-66, 2012

UDK 630*165+630*232.311.2:582.476 Taxodium distichum (L.) Rich=111

Original scientific paper

\title{
VARIABILITY IN CONE MORPHOMETRIC CHARACTERS AMONG TEST TREES OF BALD CYPRESS (Taxodium distichum L. Rich.) IN SEED STAND NEAR BAČKA PALANKA
}

\author{
Vladan POPOVIĆ ${ }^{1}$, Mirjana ŠIJAČIĆ-NIKOLIĆ ${ }^{2}$ \\ Ljubinko RAKONJAC ${ }^{1}$, Dušan JOKANOVIĆ ${ }^{2}$
}

\begin{abstract}
Bald cypress is monoecious, long-lived, deciduous conifer. It belongs to the family Taxodiaceae and genus Taxodium. In Serbia, there is only Taxodium distichum (L.) Rich. that mostly can be found in the green areas of major cities. The possibility of wider application of Bald cypress as a forest species should be based on an assessment of its genetic and adaptive potential, quantity and quality of yield, primarily at the level of the existing Bald cypress seed stand. In this paper are presented research results of the variability in cone morphometric characters among 20 test trees. The determined values of cone dimensions indicate good genetic and adaptive potential of this species that can be considered as starting point for the mass production of quality seed and planting material in Serbia.
\end{abstract}

Key words: Bald cypress, cone, seed, variability.

\section{VARIJABILNOST MORFOMETRIJSKIH SVOJSTAVA ŠIŠARICA TEST STABALA TAKSODIJUMA (Taxodium distichum L. Rich.) U SEMENSKOJ SASTOJINI KOD BAČKE PALANKE}

Izvod: Taksodijum je jednodomi, dugovečni listopadni četinar. Pripada familiji Taxodiaceae i rodu Taxodium. U Srbiji je zabeležen samo Taxodium distichum (L.) Rich. koji se uglavnom javlja pojedinačno na zelenim površina većih gradova. Mogućnost šire primene taksodijuma kao šumske vrste treba bazirati na proceni njegovog genetskog $i$

\footnotetext{
${ }^{1}$ Institut of Forestry, Belgrade, Serbia.

E-mail:vladan.popovic@forest.org.rs

${ }^{2}$ Faculty of Forestry, Belgrade, Serbia.
} 
adaptivnog potencijala kao i kvantiteta i kvaliteta uroda, pre svega, na nivou postojeće semenske sastojine taksodijuma. U radu su prikazani rezultati ispitivanja varijabilnosti morfometrijskih svojstava šišarica na nivou 20 test stabala. Utvrđene vrednosti dimenzija šišarica ukazuju na dobar genetski $i$ adaptivni potencijal ove vrste, što se može smatrati polaznom osnovom za masovnu proizvodnju kvalitetnog semenskog $i$ sadnog materijala u Srbiji.

Ključne reči: taksodijum, šišarice, seme, varijabilnost.

\section{INTRODUCTION}

Bald cypress is monoecious, long-lived, deciduous conifer. It belongs to the family Taxodiaceae and genus Taxodium that includes three species (V u k i ć e vi ć, 1987). In Serbia, there is only Taxodium distichum (L.) Rich. Bald cypress capability for establishment of forest cultures on lowland and floodplains of our country was recorded in the 1950s (P etrović, 1951; Š pirane c, 1959, 1966). At the beginning of the 1980s, Stilinović and Tucović (1970) concluded that in our environmental conditions Bald cypress can be considered as a species of rapid growth, one of the few conifer species that may be suitable for introduction of conifers on lowland and floodplain sites where it can achieve high productivity.

Nevertheless, on the territory of the Republic of Serbia this species has practically never got out from the range of horticultural activities. Researches on the variability and adaptive potential of Bald cypress in our conditions which have been published until now refer to trees that grow individually and in smaller or larger groups mainly in the city green areas (D ražić, B a to s, 2002; NinićTodorović, Ocokoljić, 2001, 2002; Tucović, Ocokoljić, 2005). The possibility of wider application of Bald cypress as a forest species should be based on an assessment of its genetic and adaptive potential as well as quantity and quality of yield, primarily at the level of the existing Bald cypress seed stand.

\section{MATERIAL AND METHOD}

Researches were conducted in Bald cypress seed stand in Bačka Palanka, registration number S 01.10.01.01, which is managed by FE Novi Sad, FA Bačka Palanka. Seed stand is within MU "Palanačke Ade- Čipski poloj", Department 11, Section a, with area of 0.22 ha and with 111 trees. Its origin is artificial, aged about 70 years, with the measured taxation values of mean diameter $\mathrm{ds}=51.7 \mathrm{~cm}$ and mean height, hs $=26.5 \mathrm{~m}$. It is located on flat ground with an average altitude of 80 $\mathrm{m}$, with a uniform slope and without clear exposure. Flooding is not present, but it is heavily influenced by underground wetting. The site on which the seed stand is located belongs to coeno-ecological group of White willow and Populus (Salicion albae) forests on undeveloped semi-gley soils.

On the basis of phenotypic characteristics and abundance of yield in 2010, 20 test trees were selected and per 200 cones were collected from each of them. Cones were put into separate bags. Then by random sampling method 50 cones per tree were taken for processing at the laboratory of Institute of Forestry. Cone 
opening was done in the dryer at the temperature of $40{ }^{\circ} \mathrm{C}$, and seed cleaning was done manually. The basic morphometric parameters of each cone (length and width) were measured by caliper with an accuracy of $1 \mathrm{~mm}$. Also, after cone opening the number of grains was determined for each cone. The obtained data were processed in a computer program Statgraph 5.0.

\section{RESULTS AND DISCUSSION}

Variability in cone morphometric characters of 20 test trees of Bald cypress is presented in Table 1.

Table 1. Variability in cone morphometric characters of 20 test trees of Bald cypress

\begin{tabular}{|c|c|c|c|c|c|c|}
\hline Trees & Parameter & $\begin{array}{c}\text { Average } \\
\text { (mm) }\end{array}$ & Min & Max & $\begin{array}{l}\text { Standard } \\
\text { deviation }\end{array}$ & $\begin{array}{c}\text { Coefficient of } \\
\text { variation }\end{array}$ \\
\hline \multirow{3}{*}{1} & Cone length $(\mathrm{mm})$ & 31.56 & 22.5 & 38.7 & 4.25 & 18.08 \\
\hline & Cone width $(\mathrm{mm})$ & 28.67 & 20.9 & 36.5 & 4.14 & 17.14 \\
\hline & $\begin{array}{l}\text { Number of seeds } \\
\text { (pcs.) }\end{array}$ & 28,50 & 22,0 & 32,0 & 2,30 & 5,28 \\
\hline \multirow{3}{*}{2} & Cone length $(\mathrm{mm})$ & 30.70 & 22.6 & 37.2 & 4.07 & 16.56 \\
\hline & Cone width (mm) & 28.44 & 22.1 & 36.0 & 3.98 & 15.85 \\
\hline & $\begin{array}{l}\text { Number of seeds } \\
\text { (pcs.) }\end{array}$ & 27,22 & 20,0 & 33,0 & 3,38 & 11,40 \\
\hline \multirow{3}{*}{3} & Cone length $(\mathrm{mm})$ & 29.67 & 22.4 & 38.4 & 4.21 & 17.76 \\
\hline & Cone width $(\mathrm{mm})$ & 27.77 & 21.3 & 34.5 & 3.40 & 15.97 \\
\hline & $\begin{array}{l}\text { Number of seeds } \\
\text { (pcs.) }\end{array}$ & 27,50 & 21,0 & 34,0 & 3,01 & 9,03 \\
\hline \multirow{3}{*}{4} & Cone length (mm) & 30.55 & 22.3 & 38.4 & 3.58 & 12.78 \\
\hline & Cone width (mm) & 27.97 & 21.0 & 36.2 & 3.47 & 12.06 \\
\hline & $\begin{array}{c}\text { Number of seeds } \\
\text { (pcs.) }\end{array}$ & 27,84 & 21,0 & 32,0 & 2,72 & 7,40 \\
\hline \multirow{3}{*}{5} & Cone length $(\mathrm{mm})$ & 30.67 & 22.6 & 37.6 & 4.01 & 16.07 \\
\hline & Cone width (mm) & 27.96 & 19.1 & 34.6 & 3.89 & 15.10 \\
\hline & $\begin{array}{l}\text { Number of seeds } \\
\text { (pcs.) }\end{array}$ & 27,06 & 20,0 & 33,0 & 3,35 & 11,24 \\
\hline \multirow{3}{*}{6} & Cone length $(\mathrm{mm})$ & 29.54 & 21.4 & 38.4 & 4.31 & 18.56 \\
\hline & Cone width $(\mathrm{mm})$ & 26.48 & 19.4 & 35.6 & 4.05 & 16.39 \\
\hline & $\begin{array}{l}\text { Number of seeds } \\
\text { (pcs.) }\end{array}$ & 26,08 & 20,0 & 32,0 & 3,30 & 10,89 \\
\hline \multirow{3}{*}{7} & Cone length $(\mathrm{mm})$ & 30.25 & 21.5 & 38.4 & 4.47 & 20.00 \\
\hline & Cone width $(\mathrm{mm})$ & 26.97 & 18.6 & 35.1 & 4.26 & 18.15 \\
\hline & $\begin{array}{l}\text { Number of seeds } \\
\text { (pcs.) }\end{array}$ & 26,66 & 20,0 & 33,0 & 3,59 & 12,88 \\
\hline \multirow{3}{*}{8} & Cone length $(\mathrm{mm})$ & 29.05 & 21.3 & 37.5 & 4.47 & 19.95 \\
\hline & Cone width $(\mathrm{mm})$ & 25.85 & 19.4 & 34.6 & 4.30 & 18.45 \\
\hline & $\begin{array}{l}\text { Number of seeds } \\
\text { (pcs.) }\end{array}$ & 25,40 & 20,0 & 33,0 & 3,58 & 14,82 \\
\hline \multirow{3}{*}{9} & Cone length $(\mathrm{mm})$ & 29.84 & 20.6 & 37.1 & 4.15 & 17.20 \\
\hline & Cone width (mm) & 26.01 & 8.0 & 33.8 & 4.89 & 23.95 \\
\hline & $\begin{array}{l}\text { Number of seeds } \\
\text { (pcs.) }\end{array}$ & 25,90 & 21,0 & 32,0 & 3,60 & 12,95 \\
\hline \multirow{3}{*}{10} & Cone length $(\mathrm{mm})$ & 29.08 & 21.3 & 38.4 & 4.26 & 18.11 \\
\hline & Cone width (mm) & 25.73 & 19.5 & 34.1 & 4.23 & 17.93 \\
\hline & $\begin{array}{l}\text { Number of seeds } \\
\text { (pcs.) }\end{array}$ & 25,44 & 20,0 & 32,0 & 3,60 & 12,99 \\
\hline \multirow{3}{*}{11} & Cone length $(\mathrm{mm})$ & 28.41 & 22.3 & 36.5 & 3.37 & 11.35 \\
\hline & Cone width (mm) & 25.27 & 20.1 & 33.2 & 3.38 & 11.45 \\
\hline & Number of seeds & 25,76 & 20,0 & 33,0 & 3,28 & 10,76 \\
\hline
\end{tabular}




\begin{tabular}{|c|c|c|c|c|c|c|}
\hline Trees & Parameter & $\begin{array}{c}\text { Average } \\
\text { (mm) }\end{array}$ & Min & Max & $\begin{array}{l}\text { Standard } \\
\text { deviation }\end{array}$ & $\begin{array}{c}\text { Coefficient of } \\
\text { variation }\end{array}$ \\
\hline & (pcs.) & & & & & \\
\hline \multirow{3}{*}{12} & Cone length $(\mathrm{mm})$ & 28.84 & 22.3 & 36.5 & 3.29 & 10.84 \\
\hline & Cone width $(\mathrm{mm})$ & 25.96 & 19.9 & 33.6 & 3.40 & 11.59 \\
\hline & $\begin{array}{c}\text { Number of seeds } \\
\text { (pcs.) }\end{array}$ & 26,30 & 21,0 & 33,0 & 2,99 & 8,95 \\
\hline \multirow{3}{*}{13} & Cone length $(\mathrm{mm})$ & 28.73 & 21.8 & 34.3 & 3,00 & 9,00 \\
\hline & Cone width $(\mathrm{mm})$ & 25.82 & 19.9 & 31.8 & 2.98 & 8.89 \\
\hline & $\begin{array}{c}\text { Number of seeds } \\
\text { (pcs.) }\end{array}$ & 26,08 & 20,0 & 33,0 & 3,15 & 9,95 \\
\hline \multirow{3}{*}{14} & Cone length $(\mathrm{mm})$ & 28.99 & 21.3 & 36.1 & 3.44 & 11.81 \\
\hline & Cone width $(\mathrm{mm})$ & 25.96 & 19.9 & 33.2 & 3.26 & 10.65 \\
\hline & $\begin{array}{c}\text { Number of seeds } \\
\text { (pcs.) }\end{array}$ & 25,86 & 20,0 & 33,0 & 3,34 & 11,14 \\
\hline \multirow{3}{*}{15} & Cone length $(\mathrm{mm})$ & 28.64 & 23.6 & 35.2 & 3.27 & 10.71 \\
\hline & Cone width $(\mathrm{mm})$ & 25.58 & 20.9 & 31.5 & 3.19 & 10.20 \\
\hline & $\begin{array}{c}\text { Number of seeds } \\
\text { (pcs.) }\end{array}$ & 25,20 & 20,0 & 33,0 & 3,73 & 13,88 \\
\hline \multirow{3}{*}{16} & Cone length $(\mathrm{mm})$ & 28.90 & 23.6 & 34.5 & 2.79 & 7.76 \\
\hline & Cone width $(\mathrm{mm})$ & 25.53 & 19.6 & 30.8 & 2.96 & 8.75 \\
\hline & $\begin{array}{c}\text { Number of seeds } \\
\text { (pcs.) }\end{array}$ & 25,56 & 20,0 & 31,0 & 3,03 & 9,19 \\
\hline \multirow{3}{*}{17} & Cone length (mm) & 28.99 & 22.8 & 36.2 & 3.49 & 12.17 \\
\hline & Cone width $(\mathrm{mm})$ & 25.78 & 19.5 & 31.2 & 2.98 & 8.86 \\
\hline & $\begin{array}{c}\text { Number of seeds } \\
\text { (pcs.) }\end{array}$ & 26,46 & 21,0 & 32,0 & 2,68 & 7,19 \\
\hline \multirow{3}{*}{18} & Cone length $(\mathrm{mm})$ & 29.13 & 23.6 & 35.2 & 2.96 & 8.74 \\
\hline & Cone width $(\mathrm{mm})$ & 26.35 & 21.2 & 32.3 & 2.81 & 7.90 \\
\hline & $\begin{array}{l}\text { Number of seeds } \\
\text { (pcs.) }\end{array}$ & 26,74 & 22,0 & 32,0 & 2,48 & 6,16 \\
\hline \multirow{3}{*}{19} & Cone length $(\mathrm{mm})$ & 29.34 & 24.3 & 35.6 & 2.92 & 8.51 \\
\hline & Cone width (mm) & 26.59 & 21.3 & 32.6 & 3.06 & 9.34 \\
\hline & $\begin{array}{c}\text { Number of seeds } \\
\text { (pcs.) }\end{array}$ & 27,08 & 21,0 & 33,0 & 3,04 & 9,22 \\
\hline \multirow{3}{*}{20} & Cone length $(\mathrm{mm})$ & 29.07 & 23.0 & 35.9 & 2.80 & 7.85 \\
\hline & Cone width (mm) & 26.05 & 21.0 & 32.1 & 2.50 & 6.25 \\
\hline & $\begin{array}{c}\text { Number of seeds } \\
\text { (pcs.) }\end{array}$ & 26,40 & 21,0 & 32,0 & 2,47 & 6,12 \\
\hline
\end{tabular}

Based on the statistical indicators, it can be concluded that the highest mean value of cone length shows a test tree marked with number $1(31.56 \mathrm{~mm})$, while the smallest mean value of cone length has the test tree marked with number $11(28.41 \mathrm{~mm})$. The highest mean value of cone width has the test tree marked with number $1(28.67 \mathrm{~mm})$ and the smallest mean value of cone width has the test tree marked with number $11(25.27 \mathrm{~mm})$. The highest mean value of number of grains has the test tree marked with number 1 (28.5 pieces), and the smallest mean value of number of grains has the test tree marked with number 15 (25.2 pieces.). Test tree marked with number 1 stands out like the best for all three characters, while the test tree number 11 has the smallest mean value of cone length and width, but not the number of grains. The values of the analyzed characters coincide with the values that in their researches obtained other authors. In Motovun forest, Croatia, Bald cypress cone diameter ranges from 20 to $25 \mathrm{~mm}$ and one cone contains from 18 to 30 grains (Š piranec, M. 1959.). Under Belgrade's environmental conditions cone diameter ranges from 20 to $30 \mathrm{~mm}$ (D r a ži ć, D., B a t o s, B. 2002.). Under the environmental conditions of Bulgaria cone diameter ranges up 
to $30 \mathrm{~mm}$, cone length from 20 to $40 \mathrm{~mm}$, and cones contain approximately 20 to 25 grains (Mile v, M ., et al. 1999.). In Bald cypress population at Veliko Ratno ostrvo, cone diameter ranges from 22 to $39 \mathrm{~mm}$, and cones contain from 10 to 32 grains, on average about 20 grains (Š i j č ić-Nikolić, M., et al. 2011.).

The coefficient of variation can be used as an indicator of statistical set homogeneity. By analyzing the values of this coefficient, we can conclude that for the cone length character the most homogeneous is the test tree marked with number 16 (7.76), and the most heterogeneous is the test tree marked with number 7 (20). For the cone width character, the most homogeneous is the test tree marked with number 20 (6.25), and the most heterogeneous is the tree test marked with number 9 (23.95). For the character number of grains, the most homogeneous is the test tree marked with number 1 (5.28), and the most heterogeneous is the test tree marked with number 8 (14.82).

\section{ANALYSIS OF VARIANCE}

\section{Cone width}

Table 2. Analysis of variance for cone width

\begin{tabular}{|c|c|c|c|c|c|}
\hline & Sum of Squares & Df & Mean Square & F- Ratio & P-Value \\
\hline Between groups & 1045.11 & 19 & 55.0058 & 4.15 & 0.0000 \\
\hline Within groups & 12977.8 & 980 & 13.2427 & & \\
\hline Total & 14022.9 & 999 & & & \\
\hline
\end{tabular}

Results of analysis of variance (Table 2) show statistically significant differences at level $p<0.05$ between cone width of 20 Bald cypress test trees.

Table 3. $L S D$ test

\begin{tabular}{|c|c|l|}
\hline Trees & Mean & Homogeneous groups \\
\hline 11 & 25.2700 & $\mathrm{X}$ \\
\hline 16 & 25.5300 & $\mathrm{X}$ \\
\hline 15 & 25.5806 & $\mathrm{XX}$ \\
\hline 10 & 25.7298 & $\mathrm{XX}$ \\
\hline 17 & 25.7780 & $\mathrm{XX}$ \\
\hline 13 & 25.8180 & $\mathrm{XX}$ \\
\hline 8 & 25.8500 & $\mathrm{XX}$ \\
\hline 12 & 25.9580 & $\mathrm{XX}$ \\
\hline 14 & 25.9620 & $\mathrm{XX}$ \\
\hline 9 & 26.0112 & $\mathrm{XX}$ \\
\hline 20 & 26.0460 & $\mathrm{XX}$ \\
\hline 18 & 26.3500 & $\mathrm{XXX}$ \\
\hline 6 & 26.4800 & $\mathrm{XXX}$ \\
\hline 19 & 26.5880 & $\mathrm{XXXX}$ \\
\hline 7 & 26.9740 & $\mathrm{XXX}$ \\
\hline 3 & 27.7660 & $\mathrm{XXX}$ \\
\hline 5 & 27.9600 & $\mathrm{XX}$ \\
\hline 4 & 27.9680 & $\mathrm{XX}$ \\
\hline 2 & 28.4380 & $\mathrm{X}$ \\
\hline 1 & 28.6676 & $\mathrm{X}$ \\
\hline
\end{tabular}

Analysis of variance shows that the differences between the mean values of cone width of 20 Bald cypress test trees are statistically significant at the 
confidence level $\mathrm{p}<0.05$. Test trees are grouped into 5 homogenous groups and with that is confirmed variability of cone width of 20 Bald cypress test trees. In the homogeneous group with the greatest cone width are test trees 1,2, 4, 5 and 3, and in the group with the smallest cone width are test trees $11,16,15$ and 10 (Table 3).

\section{Cone length}

Table 4. Analysis of variance for cone length

\begin{tabular}{|c|c|c|c|c|c|}
\hline & Sum of Squares & Df & Mean Square & F- Ratio & P- Value \\
\hline Between groups & 671.144 & 19 & 35.3233 & 2.58 & 0.0002 \\
\hline Within groups & 13416.2 & 980 & 13.69 & & \\
\hline Total & 14087.4 & 999 & & & \\
\hline
\end{tabular}

Results of analysis of variance (Table 4) show statistically significant differences at level $p<0.05$ between cone length of 20 Bald cypress test trees.

Table 5. $L S D$ test

\begin{tabular}{|c|c|l|}
\hline Trees & Mean & Homogeneous groups \\
\hline 11 & 28.410 & $\mathrm{X}$ \\
\hline 15 & 28.636 & $\mathrm{X}$ \\
\hline 13 & 28.730 & $\mathrm{X}$ \\
\hline 12 & 28.836 & $\mathrm{XX}$ \\
\hline 16 & 28.898 & $\mathrm{XX}$ \\
\hline 17 & 28.988 & $\mathrm{XX}$ \\
\hline 14 & 28.994 & $\mathrm{XX}$ \\
\hline 8 & 29.054 & $\mathrm{XX}$ \\
\hline 20 & 29.074 & $\mathrm{XX}$ \\
\hline 10 & 29.080 & $\mathrm{XX}$ \\
\hline 18 & 29.130 & $\mathrm{XXX}$ \\
\hline 19 & 29.340 & $\mathrm{XXXX}$ \\
\hline 6 & 29.544 & $\mathrm{XXXX}$ \\
\hline 3 & 29.666 & $\mathrm{XXXX}$ \\
\hline 9 & 29.844 & $\mathrm{XXXX}$ \\
\hline 7 & 30.246 & $\mathrm{XXXX}$ \\
\hline 4 & 30.554 & $\mathrm{XXX}$ \\
\hline 5 & 30.670 & $\mathrm{XX}$ \\
\hline 2 & 30.698 & $\mathrm{XX}$ \\
\hline 1 & 31.558 & $\mathrm{X}$ \\
\hline
\end{tabular}

Analysis of variance shows that the differences between the mean values of cone length of 20 Bald cypress test trees are statistically significant at the confidence level $\mathrm{p}<0.05$. Test trees are grouped into 5 homogenous groups and with that is confirmed variability of cone length of 20 Bald cypress test trees. In the homogeneous group with the greatest cone length are test trees 1, 2, 5, 4 and 7, and in the group with the smallest cone length are test trees 11,15 and 13 (Table 5).

\section{Number of grains}

Table 6. Analysis of variance for number of grains

\begin{tabular}{|c|c|c|c|c|c|}
\hline & Sum of Squares & Df & Mean Square & F- Ratio & P- Value \\
\hline Between groups & 731,496 & 19 & 38,4998 & 3.82 & 0.0000 \\
\hline Within groups & 9870,2 & 980 & 10,0716 & & \\
\hline Total & 10601,7 & 999 & & & \\
\hline
\end{tabular}


Results of analysis of variance (Table 6) show statistically significant differences at level $\mathrm{p}<0.05$ between number of grains of 20 Bald cypress test trees.

Table 7. LSD test

\begin{tabular}{|c|c|l|}
\hline Trees & Mean & \multicolumn{1}{|c|}{ Homogeneous groups } \\
\hline 15 & 25,2 & $\mathrm{X}$ \\
\hline 8 & 25,4 & $\mathrm{XX}$ \\
\hline 10 & 25,44 & $\mathrm{XXX}$ \\
\hline 16 & 25,56 & $\mathrm{XXXX}$ \\
\hline 11 & 25,76 & $\mathrm{XXXX}$ \\
\hline 14 & 25,86 & $\mathrm{XXXXX}$ \\
\hline 9 & 25,9 & $\mathrm{XXXXX}$ \\
\hline 6 & 26,08 & $\mathrm{XXXXXX}$ \\
\hline 13 & 26,08 & $\mathrm{XXXXXX}$ \\
\hline 12 & 26,3 & $\mathrm{XXXXXXX}$ \\
\hline 20 & 26,4 & $\mathrm{XXXXXX}$ \\
\hline 17 & 26,46 & $\mathrm{XXXXXX}$ \\
\hline 7 & 26,66 & $\mathrm{XXXXXX}$ \\
\hline 18 & 26,74 & $\mathrm{XXXXX}$ \\
\hline 5 & 27,06 & $\mathrm{XXXX}$ \\
\hline 19 & 27,08 & $\mathrm{XXXX}$ \\
\hline 2 & 27,22 & $\mathrm{XXX}$ \\
\hline 3 & 27,5 & $\mathrm{XX}$ \\
\hline 4 & 27,84 & $\mathrm{X}$ \\
\hline 1 & 28,5 & \\
\hline
\end{tabular}

Analysis of variance shows that the differences between the mean values of number of grains of 20 Bald cypress test trees are statistically significant at the confidence level $\mathrm{p}<0.05$. Test trees are grouped into 9 homogenous groups and with that is confirmed variability of number of grains of 20 Bald cypress test trees. In the homogeneous group with the greatest number of grains are test trees 1,4 and 3 , and in the group with the smallest number of grains are test trees 15,8 and 10 (Table 7).

Table 8. Regression analysis

\begin{tabular}{|c|c|r|r|r|r|}
\hline Trees & \multicolumn{1}{|c|}{ Parameter } & \multicolumn{1}{|c|}{$\mathbf{r}^{2}$} & \multicolumn{1}{|c|}{$\mathbf{p}$} & $\mathbf{N}$ \\
\hline \multirow{2}{*}{1} & Cone length x Number of seeds & 0,548611 & 0,300974 & 0,0000 & 50 \\
\cline { 2 - 6 } & Cone width x Number of seeds & 0,528498 & 0,27931 & 0,0001 & 50 \\
\hline \multirow{2}{*}{2} & Cone length x Number of seeds & 0,890308 & 0,792648 & 0,0000 & 50 \\
\cline { 2 - 6 } & Cone width x Number of seeds & 0,889399 & 0,791031 & 0,0000 & 50 \\
\hline \multirow{2}{*}{3} & Cone length x Number of seeds & 0,825719 & 0,681812 & 0,0000 & 50 \\
\cline { 2 - 6 } & Cone width x Number of seeds & 0,81389 & 0,662417 & 0,0000 & 50 \\
\hline \multirow{2}{*}{4} & Cone length x Number of seeds & 0,888308 & 0,789091 & 0,0000 & 50 \\
\cline { 2 - 6 } & Cone width x Number of seeds & 0,903113 & 0,815613 & 0,0000 & 50 \\
\hline \multirow{2}{*}{5} & Cone length x Number of seeds & 0,940068 & 0,883728 & 0,0000 & 50 \\
\cline { 2 - 6 } & Cone width x Number of seeds & 0,923862 & 0,853521 & 0,0000 & 50 \\
\hline \multirow{2}{*}{6} & Cone length x Number of seeds & 0,908907 & 0,826112 & 0,0000 & 50 \\
\cline { 2 - 6 } & Cone width x Number of seeds & 0,928016 & 0,861214 & 0,0000 & 50 \\
\hline \multirow{2}{*}{7} & Cone length x Number of seeds & 0,913761 & 0,834959 & 0,0000 & 50 \\
\cline { 2 - 6 } & Cone width x Number of seeds & 0,913203 & 0,83394 & 0,0000 & 50 \\
\hline \multirow{2}{*}{8} & Cone length x Number of seeds & 0,914862 & 0,836972 & 0,0000 & 50 \\
\cline { 2 - 6 } & Cone width x Number of seeds & 0,933206 & 0,870873 & 0,0000 & 50 \\
\hline \multirow{2}{*}{9} & Cone length x Number of seeds & 0,912043 & 0,831822 & 0,0000 & 50 \\
\cline { 2 - 6 } & Cone width x Number of seeds & 0,954006 & 0,910127 & 0,0000 & 50 \\
\hline \multirow{2}{*}{10} & Cone length x Number of seeds & 0,886714 & 0,786262 & 0,0000 & 50 \\
\cline { 2 - 6 } & Cone width x Number of seeds & 0,890744 & 0,793425 & 0,0000 & 50 \\
\hline 11 & Cone length x Number of seeds & 0,844746 & 0,713596 & 0,0000 & 50 \\
\hline
\end{tabular}




\begin{tabular}{|c|c|c|c|c|c|}
\hline Trees & Parameter & $\mathbf{r}$ & $\mathbf{r}^{2}$ & $\mathbf{p}$ & $\mathbf{N}$ \\
\hline & Cone width $\mathrm{x}$ Number of seeds & 0,830205 & 0,68924 & 0,0000 & 50 \\
\hline \multirow{2}{*}{12} & Cone length $x$ Number of seeds & 0,840029 & 0,705649 & 0,0000 & 50 \\
\hline & Cone width $\mathrm{x}$ Number of seeds & 0,85299 & 0,727592 & 0,0000 & 50 \\
\hline \multirow{2}{*}{13} & Cone length $\mathrm{x}$ Number of seeds & 0,752248 & 0,565877 & 0,0000 & 50 \\
\hline & Cone width $x$ Number of seeds & 0,793055 & 0,628936 & 0,0000 & 50 \\
\hline \multirow{2}{*}{14} & Cone length $\mathrm{x}$ Number of seeds & 0,858214 & 0,736531 & 0,0000 & 50 \\
\hline & Cone width $\mathrm{x}$ Number of seeds & 0,8997 & 0,80946 & 0,0000 & 50 \\
\hline \multirow{2}{*}{15} & Cone length $\mathrm{x}$ Number of seeds & 0,885102 & 0,783406 & 0,0000 & 50 \\
\hline & Cone width $\mathrm{x}$ Number of seeds & 0,910709 & 0,829391 & 0,0000 & 50 \\
\hline \multirow{2}{*}{16} & Cone length $x$ Number of seeds & 0,892438 & 0,796446 & 0,0000 & 50 \\
\hline & Cone width $\mathrm{x}$ Number of seeds & 0,913385 & 0,834272 & 0,0000 & 50 \\
\hline \multirow{2}{*}{17} & Cone length $\mathrm{x}$ Number of seeds & 0,840042 & 0,705671 & 0,0000 & 50 \\
\hline & Cone width $\mathrm{x}$ Number of seeds & 0,825407 & 0,681297 & 0,0000 & 50 \\
\hline \multirow{2}{*}{18} & Cone length $\mathrm{x}$ Number of seeds & 0,793743 & 0,630028 & 0,0000 & 50 \\
\hline & Cone width $\mathrm{x}$ Number of seeds & 0,833713 & 0,695077 & 0,0000 & 50 \\
\hline \multirow{2}{*}{19} & Cone length $\mathrm{x}$ Number of seeds & 0,864266 & 0,746956 & 0,0000 & 50 \\
\hline & Cone width $\mathrm{x}$ Number of seeds & 0,886702 & 0,78624 & 0,0000 & 50 \\
\hline \multirow{2}{*}{20} & Cone length $\mathrm{x}$ Number of seeds & 0,653156 & 0,426613 & 0,0000 & 50 \\
\hline & Cone width $\mathrm{x}$ Number of seeds & 0,711399 & 0,506089 & 0,0000 & 50 \\
\hline
\end{tabular}

Table 8 shows the coefficients of the linear correlation, the correlation coefficient (r), and the coefficient of determination $\left(r^{2}\right)$. By regression analysis was tried to link cone length and number of grains, as well as cone width and number of grains whereby is being determined only correlation. Coefficients of the linear correlation are statistically significant for the confidence level $5 \%$.

The correlation coefficient shows linear correlation of observed characters. A positive value of the correlation coefficient shows the positive correlation of observed characters. Increasing the value of one character leads to increasing the value of another. The coefficient of determination, as relative indicator, is used to determine the relationship of the observed characters. The relationship between the cone length and number of grains is the strongest in the test tree marked with number $5\left(r^{2}=0,883728\right)$, and the weakest in the test tree marked with number 1 $\left(r^{2}=0,300974\right)$. Relationship between the cone width and number of grains is the strongest in the test tree marked with number $9\left(\mathrm{r}^{2}=0,910127\right)$, and the weakest in the test tree marked with number $1\left(r^{2}=0,27931\right)$.

\section{CONCLUSIONS}

The variability of the quantity and quality of yield of more important tree species is for a long time the subject of research of forest science and profession. However, the degree of exploration of the genetic variability of quantity and quality of forest trees' seed yield and the possibility of its adequate use in our country is still below the actual needs and it is not in accordance with the economic importance. Thanks to the research results of Tucović, A. (1975), Mrva, F. (1976, 1984), Popnikola, N. (1978), Tucović, A., Stilinović, S. (1982), Tucović, A., Is ajev, V. (1985), Isajev, V. (1987), Tošić, M. (1991), Mataruga, M. (2003), Lučić, A. (2007), Lučić, A . (2012) etc., the knowledge has been gradually completed and relationship between genetic constitution of populations and environmental conditions has been explained closer, as well as the morphological and physiological characters of seed. 
To the learning about the variability in size of cones depending on the population, genotype and collection year, contributed following papers: in Scots pine T o š ić, M. (1991); L uči ć, A . (2012), in Austrian pine L uč ić , A . (2007), in Serbian spruce Isajev, V. (1987); Tucović, A. et al. (1982); ŠijačićNikolić, M. (2000, 2003) and in Spruce Šijačić-Nikolić, M. et al. (2010).

The results obtained from the analysis of variability of morphometric characteristics of cones of 20 Bald cypress test trees originated from seed stand near Bačka Palanka contribute to better understanding of relationships of analyzed characters, as well as the influence of analyzed characters on differentiation of test trees. Based on these results differences were noticed in the values of the observed characters for the each test tree individually. The test tree marked with number 1 stands out with the highest value for all three observed characters, the test tree number 11 has the smallest value for characters cone length and cone width, while the smallest value for the number of grains has test tree number 15. By regression analysis was tried to link cone length and number of grains, as well as cone width and number of grains whereby was being determined only correlation. The relationship between the cone length and number of grains is the strongest in the test tree marked with number 5 and between cone width and number of grains in the test tree number 9 . The test tree number 1 has the weakest relationship in both, the cone length and number of grains as well as the cone width and number of grains.

Conducted researches have to be continued in the direction of continuous monitoring of yield quality and quantity in Bald cypress seed stand near Bačka Palanka as the basis for the mass production of genetic quality seed and planting material of this species in Serbia.

\section{Acknowledgement}

The research is financed by the Ministry of Science and Technological Development of the Republic of Serbia, Project TR 31070 "The development of technological procedures in forestry with a view to an optimum forest cover realisation" (2011-2014).

\section{LITERATURE}

Vukićević, E. (1987): Decorative dendrology, text book. Scientific book, Belgrade. 1-580.( In original: Vukićević, E. (1987): Dekorativna dendrologija, udžbenik, Naučna knjiga, Beograd. 1-580)

Dražić D., Batos B. (2002): Bald cypress Taxodium distichum (L.) Rich. in conditions of Belgrade. Proceeding of the $7^{\text {th }}$ Symposium on Flora of Southeastern Serbia and Neighboring Regions, Dimitrovgrad (195-200). 2002. (In original: Dražić D., Batos B. (2002): Močvarni čempres (Taxodium distichum (L.) Rich.) u uslovima Beograda, Zbornik radova 7. Simpozijuma o flori jugoistočne Srbije i susednih područja, Dimitrovgrad (195200). 2002.)

Isajev, V. (1987): Serbian spruce (Picea omorika Panč) breeding on genetic-selection basis. PhD thesis - Faculty of Forestry, Belgrade (In original: Isajev, V. (1987): Oplemenjivanje 
omorike (Picea omorika Panč) na genetičko-selekcionim osnovama, Doktorska disertacija, Beograd.)

Lučić, A. (2007): Application of markers as the basis for the isolation of Austrian pine provenance regions (Pinus nigra Arn.) in Serbia. Master's Thesis. Faculty of Forestry, Belgrade. (In original: Lučić, A. (2007): Primena markera kao osnov za izdvajanje regiona provenijencija crnog bora (Pinus nigra Arn.) u Srbiji, Magistarski rad, Šumarski fakultet, Beograd.)

Lučić, A. (2012): Establishment of Scots pine (Pinus sylvestris L.) forests in Serbia based on ecological-genetic study. PhD thesis, Belgrade. (In original: Lučić, A. (2012): Podizanje šuma belog bora (Pinus sylvestris L.) u Srbiji na ekološko-genetičkim osnovama, Doktorska disertacija, Šumarski fakultet, Beograd.)

Mataruga, M. (2003): Genetic-selection bases of enhancing the seedling production of different provenances of Austrian pine (Pinus nigra Arnold). PhD thesis. Faculty of Forestry, Belgrade. (In original: Mataruga, M. (2003): Genetičko selekcione osnove unapređenja proizvodnje sadnica crnog bora (Pinus nigra Arn.) različitih provenijencija, Doktorska disertacija, Šumarski fakultet, Beograd.)

Milev M., Petkova K., Alexandrov P., Iliev N. 1999. Seeds of conifer species. Sofia, Sejani: 91. (in Bulgarian).

Mrva, F. (1976): Quantitative characters of flowering and cone yield in a clonal seed orchard of European larch. Paper presented in the section of Genetics and breeding of trees. (In original: Mrva, F. (1976): Kvantitativne karakteristike cvatnja i prinosa češera u klonalnoj semenskoj plantaži evropskog ariša. Referat u sekciji za genetiku i opleminjivanje drveća)

Mrva, F. (1984): Seed orchards of conifers in Croatia. Forestry review, 1-2 i 3-4; p:65-77. Skopje. (In original: Mrva, F. (1984): Sjemenske plantaže četinjača u Hrvatskoj. Šumarski pregled, $1-2$ i 3-4; p:65-77. Skopje.)

Ninić-Todorović, J., Ocokoljić, M. (2001): Eco-physiological characteristics of Bald cypress (Taxodium distichum L. Rich.) in Novi Sad parks. "Environmental protection of urban and suburban settlements", Eko-Conference, Novi Sad. pp: 309-313. (In original: Ninić-Todorović, J., Ocokoljić, M. (2001): Ekofiziološke karakteristike taksodijuma (Taxodium distichum L. Rich.) u parkovima Novog Sada, „Environmental protection ofurban and suburban settlements", Eko-Konferencija, Novi Sad 309-313)

Ninić-Todorović J., Ocokoljić M. (2002): Variability of Bald cypress (Taxodium distichum (L.) Rich.) populations in Novi Sad parks. Proceeding of the 7th Symposium on Flora of Southeastern Serbia and Neighboring Regions, Dimitrovgrad. pp: 121-128. (In original: Ninić-Todorović J., Ocokoljić M. (2002): Varijabilnost populacija taksodijuma (Taxodium distichum L. Rich.) u parkovima Novog Sada, Zbornik radova sa VII Simpozijuma o flori jugoistočne Srbije i susednih područja, Dimitrovgrad 121-128)

Ocokoljić, M., Tucović, A. (2005): Taxodium ascendens Brongn. - allochthonous conifer species in Serbia, Bulletin of the Faculty of Forestry, Belgrade, No. 92, pp: 159-166. (In original: Ocokoljić, M., Tucović, A. (2005): Taxodium ascendens Brongn. - alohtona vrsta četinara u Srbiji,Glasnik Šumarskog fakulteta 92, Univerzitet u Beogradu - Šumarski fakultet,Beograd 159-166)

Popnikola, N. (1978): Production of quality seeds in an experimental orchard of Scots pine (Pinus sylvestris L.) in Kruševo. Annual Bulletin of the Faculty of Forestry, No. 28. pp: 113-122. Skopje. (In original: Popnikola, N. (1978): Proizvodstvo na kvalitetno seme vo 
eksperimentalna plantaža od beli bor (Pinus sylvestris L.) vo Kruševo. Godišen zbornik na Šumarski fakultet tom 28. pp: 113-122. Skopje.)

Petrović, D. (1951): Alien species of trees (exotics) in Serbia. Belgrade (In original: Petrović, D. (1951): Strane vrste drveća (egzote) u Srbiji, SAN, Knj. 1, Beograd)

Tošić, M. (1991): Genetic variability of Scots pine (Pinus sylvestris L.) in Western Serbia as a basis for establishing criteria for the new selections. Ph.D. thesis. Faculty of Forestry, Belgrade. (In original: Tošić, M. (1991): Genetički varijabilitet belog bora (Pinus sylvestris L.) u Zapadnoj Srbiji kao osnova za utvrđivanje kriterijuma za nove selekcije, Doktorska disertacija, Šumarski fakultet, Beograd)

Tucović, A. (1975): Practicum in genetics with plant breeding. Publishing company 'Građevinska knjiga'. Belgrade. pp: 1-233. (In original: Tucović, A. (1975): Praktikum iz genetike sa oplemenjivanjem biljaka. Izdavačko preduzeće 'Građevinska knjiga'. Beograd. pp: 1-233.)

Tucović, A., Stilinović, S. (1982): Status and Problems in the production of genetic quality seed in the Socialist Republic of Serbia from seed orchards. Bulletin of the Faculty of Forestry, Belgrade, No. 58; pp: 3-21. (In original: Tucović, A., Stilinović, S. (1982): Stanje i problemi u proizvodnji genetski kvalitetnog semena u SR Srbiji iz semenskih plantaža. Gl. Šumarskog fakulteta, Beograd, Br. 58; pp: 3-21.)

Tucović, A. and V. Isajev (1985): Spontaneous and induced variability of spruce seedling from the seed object "Bela Zemlja" in region Titovo Užice. Journal of Faculty of Forestry. Belgrade, No. 64; pp: 47-65(In original: Tucović, A., Isajev, V. (1985): Spontana $i$ indukovana varijabilnost klijavaca omorike iz semenskog objekta "Bela Zemlja" u regionu Titovog Užica. . Gl. Šumarskog fakulteta, Beograd, Br. 64; pp: 47-65.)

Šijačić-Nikolić, M. (2000): Analysis of the genetic potential of generative seed orchard of Serbian spruce (Picea omorika Panč) by the controlled hybridization of half-sib lines. $\mathrm{PhD}$ thesis, Faculty of Forestry, Belgrade(In original: Šijačić-Nikolić, M. (2000): Analiza genetskog potencijala generativne semenske plantaže omorike (Picea omorika Panč) primenom kontrolisane hibridizacije linija polusrodnika, Doktorska disertacija, ŠumarskI fakultet, Beograd)

Šijačić-Nikolić, M., Isajev, V. (2003): Autogamy effects on morfometric characteristics of Serbian spruce cones. Third Interenational Balkan Botanical Congress, 18-23. May, Sarajevo, BIH, Book of abstracts. 362. (In original: Šijačić-Nikolić, M., Isajev, V. (2003): Autogamy effects on morfometric characteristics of Serbian spruce cones. Third Interenational Balkan Botanical Congress,18-23. May, Sarajevo, BIH, Book of abstracts. 362.)

Šijačić-Nikolić, M., Milovanović, J., Knežević, R. (2010): Variability of cone morphological trails and seed quality parametars of Norwey spruce sample genotypes from Kopaonik mauntain - First Serbia Forestry Congress - Future with forests, 11-13 November, 2010, Faculty of Forestry Belgrade, Serbia, Congress Abstracts, ISBN 978-867299-066-9, 157. (In original: Šijačić-Nikolić, M., Milovanović, J., Knežević, R. (2010): Variability of cone morphological trails and seed quality parametars of Norwey spruce sample genotypes from Kopaonik mauntain - First Serbia Forestry Congress - Future with forests, 11-13 November, 2010, Faculty of Forestry Belgrade, Serbia, Congress Abstracts, ISBN 978-86-7299-066-9, 157.) 
Šijačić-Nikolić M. Vilolić D., Veselinović M., Mitrović S., Jokanović D. (2010): Bald cypress (Taxodium distichum (L.) rich.) in the protected area Veliko ratno ostrvo. Bulletin of the Faculty of Forestry, Belgrade No.103, pp. 173-184. (In original: Šijačić-Nikolić M. Vilolić D., Veselinović M., Mitrović S., Jokanović D. (2010): Močvarni čempres (Taxodiumn distichum (L.) Rich.) na području zaštićenog prirodnog dobra Veliko ratno ostrvo, Glasnik Šumarskog fakulteta, Beograd, br. 103, str. 173-184.)

Špiranec M. (1959): Bald cypress and possibility of its cultivation in our country. Forestry review No. 6-7. Zagreb: 182-193). (In original: Špiranec M. (1959): Močvarni taksodij $i$ mogućnost njegova uzgoja u našim krajevima. Šumarski list br. 6-7. Zagreb: 182-193) 